\title{
New Volatile Constituents from Leaves of Stemodia trifoliata (Link.) Reichb. (Schrophulariaceae)
}

\author{
Wildson Max B. da Silva, João Carlos da C. Assunção, Renata M. Araújo, Edilberto R. Silveira \\ and Otília D. L. Pessoa*
}

\author{
Departamento de Química Orgânica e Inorgânica, Centro de Ciências, Universidade Federal do Ceará, \\ CP 12.200, 60021-970 Fortaleza-CE, Brazil
}

\begin{abstract}
Os óleos essenciais das folhas de Stemodia trifoliata (Scrophulariaceae), coletadas nos meses de agosto de 2005 e 2006, foram analisados por CG-EM e CG-DIC. Um total de 22 componentes voláteis, representados por sesquiterpenos e diterpenos, foi identificado. $\beta$-Cariofileno $(9,4-15,4 \%)$ e óxido de cariofileno $(6,2-9,0 \%)$ foram os principais componentes identificados na fração sesquiterpênica, enquanto os diterpenóides $6 \alpha$-acetóxi-óxido de manoúla $(13,9-23,2 \%)$ e 6 $\alpha$-hidróxi-óxido de manoíla $(25,1-29,7 \%)$ foram os constituintes majoritários da fração diterpênica. Estes diterpenos, derivados do óxido de manoíla, são novos e suas estruturas foram determinadas por métodos espectroscópicos, particularmente RMN 1D e 2D. A investigação química dos componentes voláteis de $S$. trifoliata é descrita pela primeira vez neste trabalho.
\end{abstract}

The leaf essential oils of Stemodia trifoliata (Scrophulariaceae), collected at the same month of two different years (August 2005 and 2006), were analized by GC-MS and GC-FID. A total of 22 volatile components represented by sesquiterpenes and diterpenes was identified. $\beta$-Caryophyllene (9.4-15.4\%) and caryophyllene oxide (6.2-9.0\%) were the major compounds identified in the sesquiterpene fraction, while the diterpenoids $6 \alpha$-acetoxymanoyl oxide (13.9-23.2\%) and 6 $\alpha$-hydroxymanoyl oxide (25.1-29.7\%) were the main constituents of the diterpene fraction. The two novel manoyl oxide derivatives had their structures established by means of spectroscopic methods, particularly 1D and 2D NMR. This work describes for the first time the chemical investigation on the volatile composition of S. trifoliata.

Keywords: Stemodia trifoliata, essential oil, manoyl oxide diterpenes, sesquiterpenes

\section{Introduction}

The genus Stemodia (Scrophulariaceae) comprises approximately 40 species represented by annual herbs and shrubs distributed in Asia, Africa, Australia and the Americas. ${ }^{1}$ In accordance with a literature survey only five Stemodia species (S. maritima, S. chilensis, S. kingii, $S$. viscosa and $S$. foliosa) have been previously studied. ${ }^{1-5}$ Secondary metabolites such as cucurbitacins, stearic acid derivatives and flavonoids have been isolated, but diterpenes containing an unusual tetracyclic skeleton, known as stemodane, are the most characteristic compounds elaborated by plants of this genus. These compounds bear a close resemblance to aphidicolin, a potent cytotoxic and antiviral diterpenoid isolated from Cephalosporium

*e-mail: opessoa@ufc.br aphidicola and, by this reason have been the subject of innumerous biotransformations. ${ }^{6-9}$ S. trifoliata (Link) Reichb. is an annual plant, herbaceous and pubescent. Due to its preference by fertile and humid soils it is commonly found in flower beds, orchards and back yard gardens. ${ }^{10}$

In the present work, the chemical composition of the essential oil from the leaves of a wild population of $S$. trifoliata, as well as the isolation of two novel labdane diterpenes, are described. This is the first report on the phytochemical investigation of $S$. trifoliata and on the volatile chemical composition of a Stemodia species.

\section{Results and Discussion}

The essential oils of $S$. trifoliata, collected in August of two different years (2005 and 2006), but from the same site, were analyzed by GC-MS and GC-FID. The chemical 
composition of the oils, including the retention index and the percentage of each constituent is presented at Table 1. A total of 22 components was identified, representing 87.0 and $92.6 \%$ of the whole oils samples. Except by the presence of $(E)-3$-hexenol (2.6\%), detected just in one of the analyzed oils, they were composed mainly by sesquiterpenes (33.2-48.0\%) and diterpenes (44.6$51.2 \%$ ), but the prevalent components were the same in both oils. In spite of this, marked qualitative differences were observed for the two oils, since a higher number of sesquiterpenes were identified for the sample B. Among the identified sesquiterpenes $\beta$-caryophyllene (9.4-15.4\%) and caryophyllene oxide (6.2-9.0\%) were the major ones. The diterpene fraction was dominated by manoyl oxide derivatives, which were identified as $6 \alpha$-hydroxymanoyl oxide (25.1-29.7\%) and $6 \alpha$-acetoxymanoyl oxide (13.9-
23.2\%). In the GC-MS preliminary analysis of the oils, the peaks corresponding to $6 \alpha$-hydroxymanoyl oxide (KI 1878) and $6 \alpha$-acetoxymanoyl oxide (KI 1895), were not identified from their Kovats Indices and mass spectra. For this reason, an aliquot of the combined essential oils (samples A and B), was subjected to flash chromatography yielding both compounds, in the pure forms. Their structures were unequivocally elucidated by spectroscopy, especially NMR, including 1D and 2D experiments (Table 2).

Compound $\mathbf{1}$ was isolated as a colorless oil and its molecular formula $\mathrm{C}_{22} \mathrm{H}_{36} \mathrm{O}_{3}$ was deduced by a combination of ${ }^{13} \mathrm{C}$ NMR spectral data and EIMS $\left(\mathrm{m} / \mathrm{z} 333,[\mathrm{M}]^{+}-\mathrm{CH}_{3}\right)$. Even though the molecular ion of $\mathbf{1}$ has not been detected it is plausible to speculate the loss of Me-16 to afford peak $\mathrm{m} / \mathrm{z} 333(5 \%)$ after the stability conferred by the conjugation of the positive charge with the vinyl group increased by the

Table 1. Chemical composition of the leaf oils of Stemodia trifoliate

\begin{tabular}{|c|c|c|c|c|}
\hline Constituents $^{\mathrm{a}}$ & $\mathrm{RI}^{\mathrm{b}}$ & $\mathrm{A} /(\%)^{\mathrm{c}}$ & $\mathrm{B} /(\%)^{\mathrm{d}}$ & Identification \\
\hline (E)-3-hexenol & 706 & 2.6 & - & MS, RI \\
\hline$\alpha$-copaene & 1389 & 3.8 & 3.9 & MS, RI \\
\hline$\beta$-caryophyllene & 1434 & 9.4 & 15.4 & MS, RI \\
\hline$\alpha$-humulene & 1467 & - & 1.6 & MS, RI \\
\hline$\gamma$-muurolene & 1488 & - & 1.3 & MS, RI \\
\hline germacrene D & 1493 & - & 1.4 & MS, RI \\
\hline$\gamma$-amorphene & 1505 & - & 1.2 & MS, RI \\
\hline bicyclogermacrene & 1508 & - & 2.1 & MS, RI \\
\hline$\delta$-amorphene & 1524 & - & 0.8 & MS, RI \\
\hline$\delta$-cadinene & 1533 & 4.0 & 5.7 & MS, RI \\
\hline$\alpha$-calacorene & 1549 & - & 1.2 & MS, RI \\
\hline (E)-nerolidol & 1567 & - & 1.8 & MS, RI \\
\hline spathulenol & 1582 & - & 0.8 & MS, RI \\
\hline caryophyllene oxide & 1588 & 9.0 & 6.2 & MS, RI \\
\hline$\beta$-copaen-4- $\alpha$-ol & 1628 & 1.5 & - & MS, RI \\
\hline caryophylla-4(14),8(15)dien-5-ol & 1636 & 5.5 & 2.1 & MS, RI \\
\hline epi- $\alpha$-muurolol & 1639 & - & 1.2 & MS,RI \\
\hline$\alpha$-cadinol & 1651 & - & 1.3 & MS, RI \\
\hline manoyl oxide & 1829 & 1.4 & 1.0 & MS, RI \\
\hline phytol & 1865 & 1.5 & - & MS, RI \\
\hline 6 $\alpha$-hydroxymanoyl oxide & 1878 & 25.1 & 29.7 & MS, NMR \\
\hline $6 \alpha$-acetoxymanoyl oxide & 1895 & 23.2 & 13.9 & MS, NMR \\
\hline Sesquiterpenes & & 33.2 & 48.0 & \\
\hline Diterpenes & & 51.2 & 44.6 & \\
\hline Others & & 2.6 & - & \\
\hline Total & & 87.0 & 92.6 & \\
\hline
\end{tabular}

${ }^{\mathrm{a}}$ Constituents listed in order of elution on DB-5 column; ${ }^{\mathrm{R} I}=$ Kovats retention index according to $n$-alkanes $\left(\mathrm{C}_{8}-\mathrm{C}_{26}\right) ;{ }^{\mathrm{c}} \mathrm{A}=$ Essential oil percentage of S. trifoliata collected in August 2005; ${ }^{\mathrm{d}} \mathrm{B}=$ Essential oil percentage of S. trifoliata collected in August 2006; ${ }^{\mathrm{e}}$ Methods used in the identification of the volatile constituents. 
Table 2. ${ }^{1} \mathrm{H}$ and ${ }^{13} \mathrm{C}$ NMR spectral data for compounds $\mathbf{1}$ and $\mathbf{2}$, in $\mathrm{CDCl}_{3}^{\mathrm{a}}$

\begin{tabular}{|c|c|c|c|c|}
\hline \multirow[t]{2}{*}{ Atom } & \multicolumn{2}{|r|}{1} & \multicolumn{2}{|r|}{2} \\
\hline & $\delta_{\mathrm{C}}$ & $\delta_{\mathrm{H}}$ & $\delta_{\mathrm{C}}$ & $\delta_{\mathrm{H}}$ \\
\hline 1 & 39.0 & $1.56,0.88$ & 39.2 & $1.53,0.88$ \\
\hline 2 & 18.4 & $1.56,1.43$ & 18.5 & $1.61,1.45$ \\
\hline 3 & 43.6 & $1.39,1.22$ & 43.8 & $1.38,1.25$ \\
\hline 4 & 33.5 & - & 33.9 & - \\
\hline 5 & 59.1 & 1.32 & 61.9 & 1.04 \\
\hline 6 & 71.1 & $5.11(\mathrm{td}, 11.4,4.0)$ & 69.4 & $3.88(\mathrm{td}, 11.0,3.9)$ \\
\hline \multirow[t]{2}{*}{7} & 50.1 & $2.12(\mathrm{dd}, 11.5,4.0)$ & 54.8 & $2.19(\mathrm{dd}, 11.5,3.9)$ \\
\hline & & 1.57 & & 1.59 \\
\hline 8 & 74.3 & - & 74.5 & - \\
\hline 9 & 54.3 & 1.48 & 54.4 & 1.48 \\
\hline 10 & 38.1 & - & 37.9 & - \\
\hline 11 & 15.7 & $1.60,1.47$ & 15.7 & $1.57,1.46$ \\
\hline 12 & 34.8 & $1.78,1.66$ & 34.9 & $1.61,1.46$ \\
\hline 13 & 73.7 & - & 73.3 & - \\
\hline 14 & 147.8 & $5.87(\mathrm{dd}, 17.3,10.7)$ & 147.9 & $5.90(\mathrm{dd}, 17.4,10.8)$ \\
\hline \multirow[t]{2}{*}{15} & 110.7 & $5.16(\mathrm{dd}, 17.3,1.4)$ & 110.6 & $5.20(\mathrm{dd}, 17.4,1.2)$ \\
\hline & & $4.94(\mathrm{dd}, 10.7,1,4)$ & & $4.96(\mathrm{dd}, 10.6,1.2)$ \\
\hline 16 & 29.4 & $1.24(\mathrm{~s})$ & 29.5 & $1.27(\mathrm{~s})$ \\
\hline 17 & 27.1 & $1.39(\mathrm{~s})$ & 27.3 & $1.34(\mathrm{~s})$ \\
\hline 18 & 36.2 & $1.00(\mathrm{~s})$ & 36.6 & $1.17(\mathrm{~s})$ \\
\hline 19 & 22.2 & $0.86(\mathrm{~s})$ & 22.1 & $1.01(\mathrm{~s})$ \\
\hline 20 & 16.6 & $0.88(\mathrm{~s})$ & 16.7 & $0.84(\mathrm{~s})$ \\
\hline 21 & 170.3 & - & & \\
\hline 22 & 22.1 & $2.02(\mathrm{~s})$ & & \\
\hline
\end{tabular}

${ }^{a}$ All hydrogen and carbon assignments were made based on DEPT $135^{\circ}$, ${ }^{1} \mathrm{H},{ }^{1} \mathrm{H}-\mathrm{COSY}, \mathrm{HMQC}$ and HMBC experiments; Chemical shifts $(\delta)$ in ppm; Coupling constants $(J)$ in $\mathrm{Hz}$; Several multiplicities were not determined due to bond complexity or superimposition.

donation of the electron pair from the oxygen. From this ion the deacetylation would generate a more abundant ion at $\mathrm{m} / z 273$ (38\%), see supplementary data. The molecular formula accounted for five degrees of unsaturation, one of them represented by a acetoxyl group at $\delta 170.3$ in the ${ }^{13} \mathrm{C}$ NMR spectrum, corroborated by the $1733 \mathrm{~cm}^{-1}$ absorption in the FTIR spectrum. A second unsaturation was related to a vinyl group inferred from the typical ${ }^{13} \mathrm{C}$ NMR signals at $147.8(\mathrm{CH}-14)$ and $110.7\left(\mathrm{CH}_{2}-15\right)$, and ${ }^{1} \mathrm{H}$ NMR signals at $\delta 5.87(1 \mathrm{H}, \mathrm{dd}, J=17.3$ and $10.7 \mathrm{~Hz}, \mathrm{H}-14), 5.16(1 \mathrm{H}$, $\mathrm{dd}, J=17.3$ and $1.4 \mathrm{~Hz}, \mathrm{H}-15 \mathrm{a})$ and $4.94(1 \mathrm{H}, \mathrm{dd}, J=10.7$, $1.4 \mathrm{~Hz}, \mathrm{H}-15 \mathrm{~b}$ ). The ${ }^{13} \mathrm{C}$ NMR (CPD) spectrum showed the presence of 22 carbon signals assigned to five methyls, six methylenes, three methines, a vinyl moiety, one acetyl group, as well as to four non-hydrogenated carbon atoms after comparison with both DEPT 135 and HMQC spectra.
The above data are consistent with a manoyl oxide diterpene with an acetoxy substituent. The presence of the acetylated hydroxyl group at the C-6 position was supported by the observed ${ }^{3} J_{\text {C-H }}$ long-range correlations displayed for H-6 $(\delta 5.11, \mathrm{td}, J=4.0$ and $11.4 \mathrm{~Hz}$ ) and the carbon signals at $\delta 170.3$ (C-21) and 74.5 (C-8). In the HMBC spectrum the correlation of $\mathrm{H}-14(\delta 5.87, \mathrm{dd}, J=10.7$ and $17.3 \mathrm{~Hz})$ with the carbon signal at $\delta 29.4$ was sufficient to assure the correct assignment of $\mathrm{CH}_{3}-16 .{ }^{11}$ The 4-axial orientation inferred to this methyl group was in agreement with the chemical shift at $\delta 29.4$. The proposed relative stereochemistry was further supported by the NOESY experiment, which clearly revealed dipolar interaction between $\mathrm{CH}_{3}-16 / \mathrm{CH}_{3}-17$ and $\mathrm{CH}_{3}-16 / \mathrm{H}-12$ eq. Similarly, the $\alpha$-equatorial orientation suggested to the acetyl group was defined based on nOe correlations of H-6 with the methyl groups 17, 19 and 20. Additional nOe effects observed for $\mathrm{H}-5 / \mathrm{H}-7 \mathrm{ax} / \mathrm{H}-9 \mathrm{ax}$; H-1ax/H-9ax and, H-9ax/H-12ax (Figure 2) supported the stereochemistry established for 1 . Complete assignments of the NMR data of $\mathbf{1}$ were achieved by ${ }^{1} \mathrm{H},{ }^{1} \mathrm{H}-\mathrm{COSY}, \mathrm{HMQC}$, HMBC and NOESY experiments. Thus, the structure of the new diterpene was unambiguously established as the $6 \alpha$-acetoxymanoyl oxide.

Compound 2 was also isolated as colorless oil and its molecular formula $\mathrm{C}_{20} \mathrm{H}_{34} \mathrm{O}_{2}$ was deduced by a combination of NMR ${ }^{13} \mathrm{C}$ spectral data and EIMS $\left(\mathrm{m} / \mathrm{z}, 291,[\mathrm{M}]^{+}\right.$$\mathrm{CH}_{3}$ ). The same kind of explanation used for 1 should be used here to justify the peak at $\mathrm{m} / z 273$ (12\%) after dehydration from $\mathrm{m} / z 291$ (24\%). This molecular formula
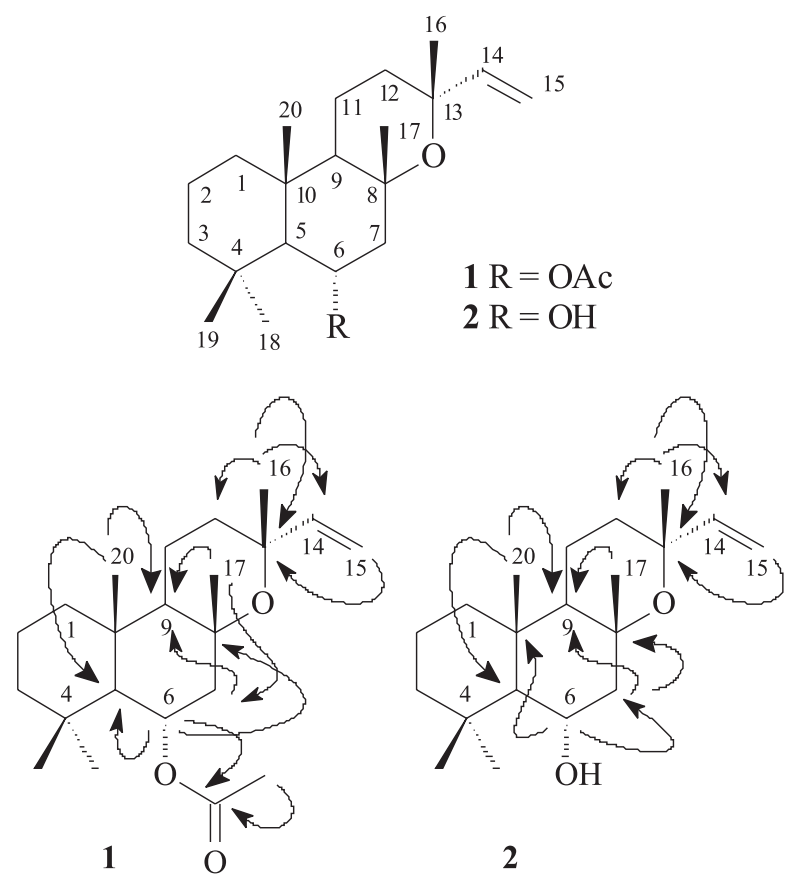

Figure 1. Selected HMBC correlations (depicted by single arrows) for compounds $\mathbf{1}$ and $\mathbf{2}$. 

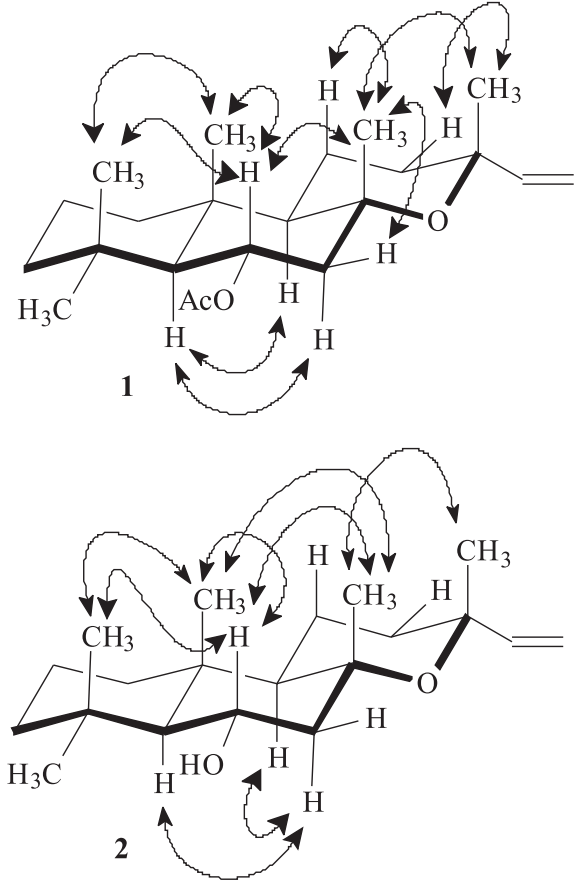

Figure 2. Selected NOESY correlations (depicted by double arrows) for compounds $\mathbf{1}$ and $\mathbf{2}$.

along with the ${ }^{1} \mathrm{H}$ and ${ }^{13} \mathrm{C}$ NMR spectra similarities for both compound suggested that compound 2 could be the corresponding alcohol of $6 \alpha$-acetoxymanoyl oxide, $\mathbf{1}$. This was reinforced by the absence of the typical signals of the acetyl group. Moreover, the oxymethine proton (H-6) was shifted highfield $(\delta 3.88)$ in 2 compared with that at $\delta 5.11$ in $\mathbf{1}$. The expected deshielding effect on the chemical shifts of carbons C-5 $(\delta 61.9)$ and C-7 $(\delta 54.8)$ when compared with those of $\mathbf{1}(\delta 59.1, \mathrm{C}-5 ; \delta 50.1, \mathrm{C}-7)$ was in agreement with the presence of a hydroxyl group in C-6 after the disappearance of the $\gamma$-effect of the acetyl group. This was also supported by the HMBC data (Figure 1). The NOESY experiment (Figure 2) showed that the stereochemistry of diterpene $\mathbf{2}$ was consistent with that established for $\mathbf{1}$. It is worthy of notice that the isomer $6 \alpha$-hydroxy-13-epimanoyl oxide has been previously isolated from southern pine (Pinus spp.) tall oil. ${ }^{12}$

\section{Experimental}

\section{General experimental procedures}

The qualitative analysis was carried out on a Shimadzu GC-17A/QP5050 using a non-polar OV-5 fused silica capillary column $(30 \mathrm{~m} \times 0.25 \mathrm{~mm}$ i.d., $0.25 \mu \mathrm{m}$ film thickness); carrier gas helium, flow rate $1 \mathrm{~mL} \mathrm{~min}^{-1}$ and with split mode (ratio 1:48). The injector temperature and detector temperature were 250 and $280{ }^{\circ} \mathrm{C}$, respectively. The column temperature was programmed from 40 to
$180{ }^{\circ} \mathrm{C}$ at $4{ }^{\circ} \mathrm{C} \mathrm{min}^{-1}$ and then 180 to $250^{\circ} \mathrm{C}$ at $20^{\circ} \mathrm{C} \mathrm{min}^{-1}$ and held isothermal for $7 \mathrm{~min}$. Mass spectra were recorded from 30-450 $\mathrm{m} / \mathrm{z}$. NMR spectra were recorded on a Bruker Avance DRX-500 (500 MHz for ${ }^{1} \mathrm{H}$ and $125 \mathrm{MHz}$ for ${ }^{13} \mathrm{C}$ ) spectrometer equipped with $5 \mathrm{~mm}$ inverse detection z-gradient probe. The chemical shifts, given on the d scale, were referenced to the residual undeuterated $\mathrm{CHCl}_{3}$ portion $\left(\delta_{\mathrm{H}}\right.$ 7.27) and, the center peak of the deuterated $\mathrm{CDCl}_{3}$ $\left(\delta_{\mathrm{C}} 77.23\right)$.

Column chromatography was run using silica gel 60, particle size 0.040-0.063 (230-400 mesh, EMD/Merck), while TLC was performed on precoated plates (silica gel $60 \mathrm{~F}_{254}$, Merck, Germany) and compounds detected by spraying with vanillin/perchloric acid/EtOH solution followed by heating at $120^{\circ} \mathrm{C}$.

\section{Plant material}

The leaves of S. trifoliata were collected during the flowering stage, in August 2005 and 2006, from a population growing on the road margins at Pico Alto, Guaramiranga ridge (Ceará State, Brazil), at an elevation of approximately $1000 \mathrm{~m}$. A voucher specimen (No. 39550) has been deposited at the Herbário Prisco Bezerra (EAC) of the Departamento de Biologia, Universidade Federal do Ceará.

\section{Essential oil distillation}

The fresh leaves of $S$. trifoliata were hydrodistilled in a Clevenger-type apparatus for a period of $2 \mathrm{~h}$ to afford yellowish oils, which were dried over $\mathrm{Na}_{2} \mathrm{SO}_{4}$, stored in sealed glass vials and preserved under refrigeration before analysis. The yield of the oils $(0.02 \%, \mathrm{~m} / \mathrm{m})$, were calculated on fresh weight of the plant materials.

\section{Isolation of compounds $\mathbf{1}$ and $\mathbf{2}$}

An aliquot of the leaf essential oil ( $86 \mathrm{mg}$ ) of S. trifoliata, was subjected to silica gel column flash chromatography using a gradient of $n$-hexane: $\mathrm{CH}_{2} \mathrm{Cl}_{2} 4: 6$ to give 72 fractions of approximately $8 \mathrm{~mL}$ each. After TLC analysis, fractions 65 to 67 were combined $(48 \mathrm{mg}$ ) and further submitted to silica gel flash chromatography using $\mathrm{CH}_{2} \mathrm{Cl}_{2}$ as eluent to yield the pure compounds $\mathbf{1}(17 \mathrm{mg})$ and $\mathbf{2}(10 \mathrm{mg})$.

\section{Compound identification}

The individual components of the oil were identified on the basis of their $\mathrm{GC}$ retention indices (RI) with reference to a homologous series of $\mathrm{C}_{8}-\mathrm{C}_{26} n$-alkanes, and by matching 
their $70 \mathrm{eV}$ mass spectra with those of the spectrometer data base using the Wiley Class-5000 library and, by comparison of the fragmentation patterns of the mass spectra with those reported in the literature. ${ }^{13}$ The structures of the new volatile diterpenes ( $\mathbf{1}$ and $\mathbf{2}$ ) were elucidated based on spectroscopic analysis and comparison with published data for known manoyl oxide diterpenes. ${ }^{11}$

\section{0-Acetoxymanoyl oxide (1)}

Colorless oil; $[\alpha]_{\mathrm{D}}^{20}+25^{\circ}\left(c 0.3, \mathrm{CHCl}_{3}\right)$; IR $(\mathrm{KBr})$ $\mathrm{v}_{\max } / \mathrm{cm}^{-1} 2928,2869,1733,1459,1374,1244,1026 ; \mathrm{EM}$ (70 eV) 333, 273, 255, 190, 175, 135, 119, 81; ${ }^{1} \mathrm{H}(500$ $\mathrm{MHz})$ and ${ }^{13} \mathrm{C}$ NMR (125 MHz) data, see Table 1.

6 $\alpha$-Hydroxy-13-epimanoyl oxide (2)

Colorless oil; $[\alpha]_{\mathrm{D}}^{20}+20^{\circ}\left(\right.$ c $\left.0.2, \mathrm{CHCl}_{3}\right)$; IR $(\mathrm{KBr})$ $v_{\max } / \mathrm{cm}^{-1} 3431,3005,2924,1465,1378,1070 ; \mathrm{EM}(70 \mathrm{eV})$ 291, 273, 255, 2001, 190, 135, 121, 109, 81, 69; ${ }^{1} \mathrm{H}(500$ $\mathrm{MHz})$ and ${ }^{13} \mathrm{C}$ NMR (125 MHz) data, see Table 1.

\section{Acknowledgments}

The authors are grateful to CNPq, CAPES, FUNCAP and PRONEX for financial support and research fellowships.

\section{Supplementary Information}

Supplementary information for compounds $\mathbf{1}$ and $\mathbf{2}$ is available free of charge as PDF file at http://jbcs.sbq.org.br.

\section{References}

1. Chamy, M. C.; Piovano, M.; Garbarino, J. A.; Gambaro, V.; Phytochemistry 1991, 30, 1719.

2. Hufford, C. D.; Oguntimein, B. O.; Muhammad, I.; J. Nat. Prod. 1992, 55, 48.

3. Allen, J. G.; Colegate, S. M.; Mitchell, A. A.; Mulder, R. J.; Raisbeck, M. F.; Phytochem. Anal. 2006, 17, 226.

4. Ramesh, P.; Ramavhandran, N. A. G.; Sankara, S. S.; Pondicherry 1979, 48, 67.

5. Silva, L. L. D.; Nascimento, M.; Silva, D. H. S.; Furlan, M.; Bolzani, V. S.; Planta Med. 2002, 68, 1137.

6. Chen, A. R. M.; Reese, P. B.; Phytochemistry 2002, 59, 57.

7. Martin, G. D. A.; Reynolds, W. F.; Reese, P. B.; Phytochemistry 2005, 66, 901.

8. Chen, A. R. M.; Ruddock, P. L. D.; Lamm, A. S.; Reynolds, W. F.; Reese, P. B.; Phytochemistry 2005, 66, 1898.

9. Lamm, A. S.; Reynolds, W. F.; Reese, P. B.; Phytochemistry 2006, 67, 1088.

10. Lorenzi H.; Plantas Daninhas do Brasil. Terrestres, Aquáticas, Parasitas e Tóxicas. Instituto Plantarum de Estudos da Flora Ltda. $3^{a}$. ed. Nova Odessa: São Paulo, 2000. p. 546.

11. Chang, C. W. J.; Flament, I.; Matson, J. A.; Nishida, T.; Ohloff, G.; Wehrli, F. W.; Weinheimer, A. J.; Progress in the Chemistry of Organic Natural Products. Springer Verlag Wien: New York, vol. 36, 1979, p. 56.

12. Conner, A. H.; Rowe, J. W.; Phytochemistry 1977, 16, 1777.

13. Adams, R. P.; Identification of Essential Oil Components by Gas Chromatography/Quadrupole Mass Spectroscopy. Allured Publishing Corporation, Carol Stream, Illinois: USA, 2001.

Received: April 22, 2008

Web Release Date: October 21, 2008 


\section{New Volatile Constituents from Leaves of Stemodia trifoliata (Link.) Reichb. (Schrophulariaceae)}

Wildson Max B. da Silva, João Carlos da C. Assunção, Renata M. Araújo, Edilberto R. Silveira and Otília D. L. Pessoa*

Departamento de Química Orgânica e Inorgânica, Centro de Ciências, Universidade Federal do Ceará, CP 12.200, 60.021-970, Fortaleza-CE, Brazil<smiles>[R]C1C[C@]2(C)O[C@@](C)(C=C)CCC2[C@@]2(C)CCCC(C)(C)[C@@H]12</smiles>

$1 \mathrm{R}=\mathrm{OAc}, m / z 348[\mathrm{M}]^{+}$

$2 \mathrm{R}=\mathrm{OH}, m / z 306[\mathrm{M}]^{+}$<smiles>[R]C1C[C@]2(C)O[C@@H](C=C)CC[C@H]2[C@@]2(C)CCCC(C)(C)[C@@H]12</smiles>

1a $\mathrm{R}=\mathrm{OAc}, m / z 333(5 \%)$

2a $\mathrm{R}=\mathrm{OH}, m / z 291(24 \%)$<smiles>C=C[C@H]1CCC2[C@](C)(CC=C3C(C)(C)CCC[C@@]32C)O1</smiles>

1b $m / z 273(38 \%)$

2b $m / z 273(12 \%)$

Scheme S1. Important fragment ions observed in the mass spectra of $\mathbf{1}$ and $\mathbf{2}$.

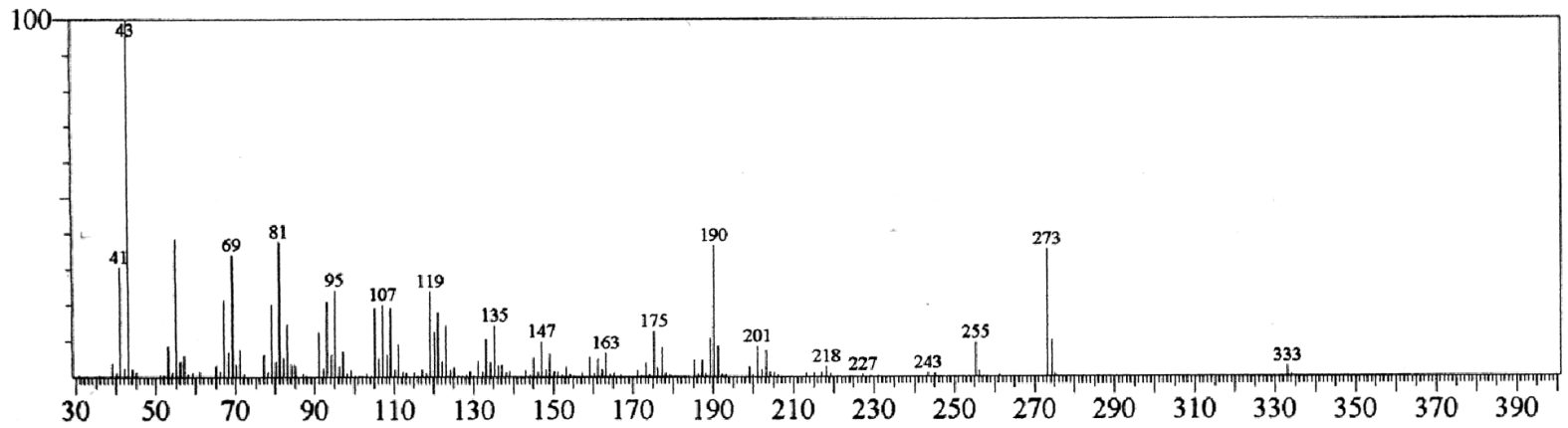

Figure S1. Mass spectrum of compound 1.

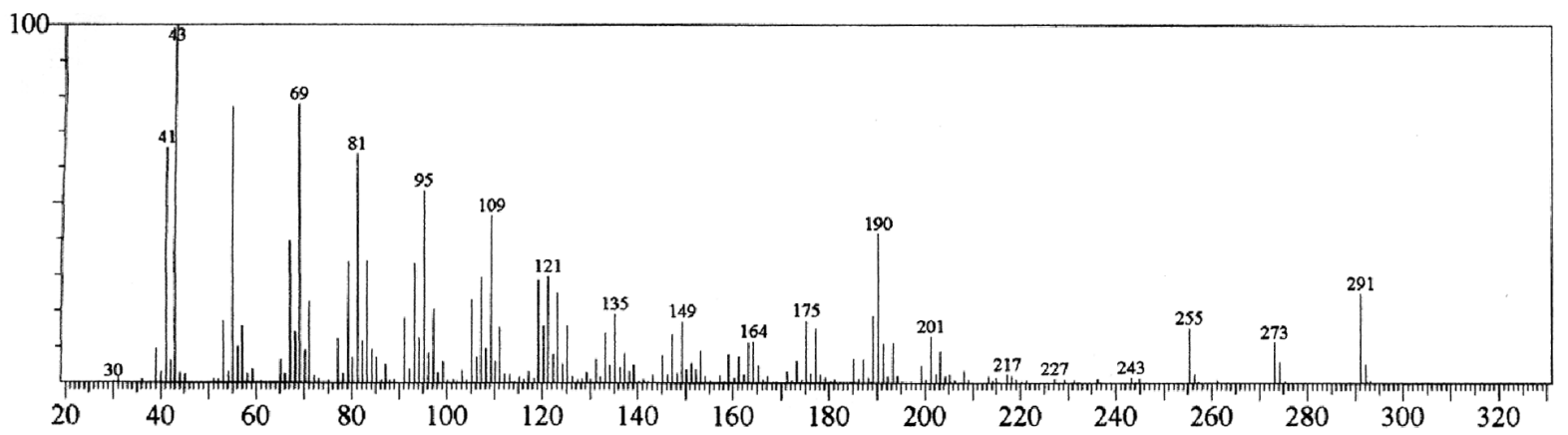

Figure S2. Mass spectrum of compound 2 . 
至
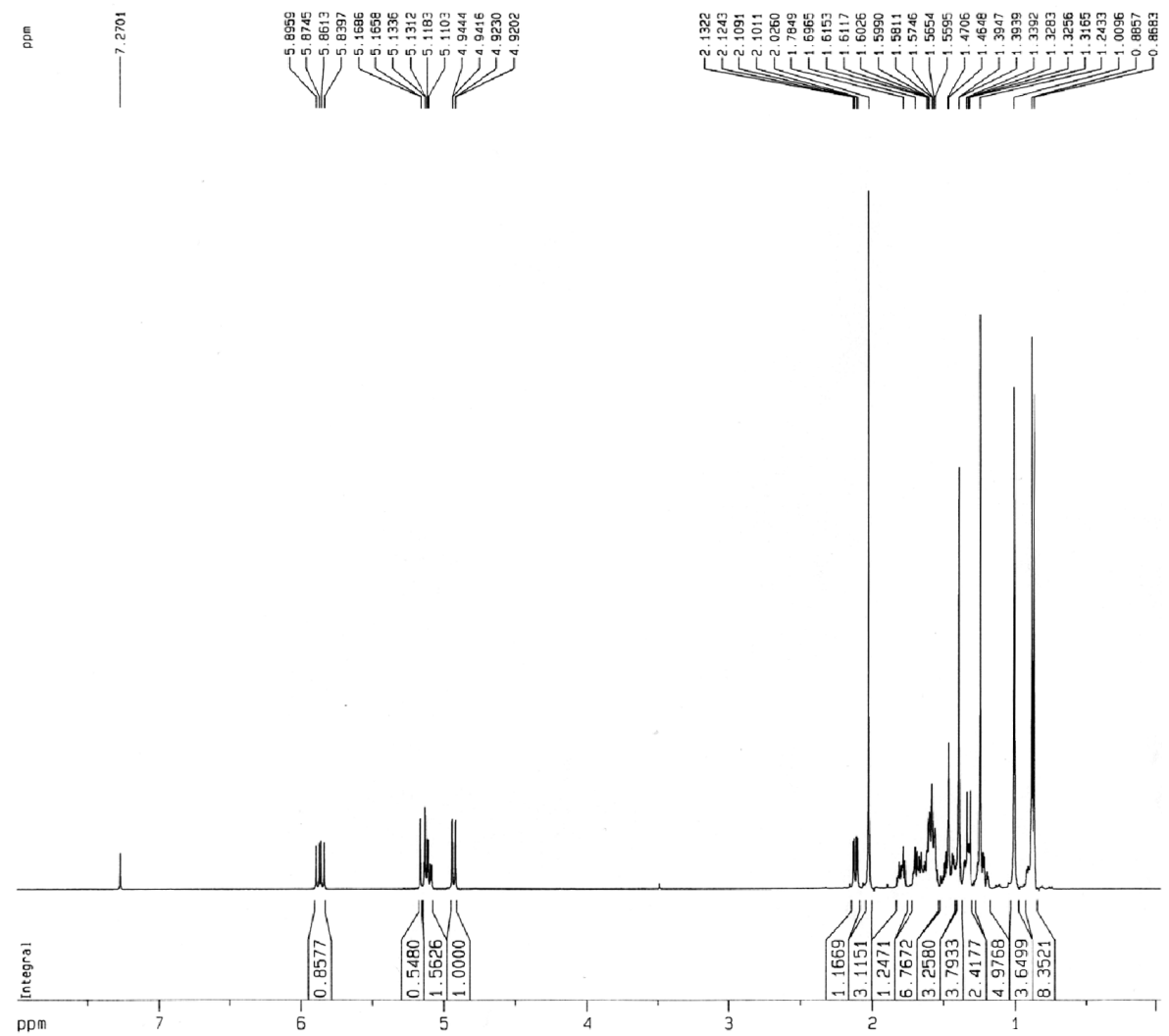

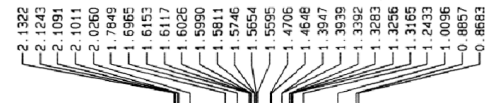

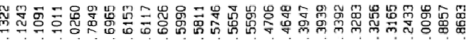

II)

Figure S3. ' $\mathrm{H}$ NMR spectrum of compound $\mathbf{1}\left(\mathrm{CDCl}_{3}, 500 \mathrm{MHz}\right)$.
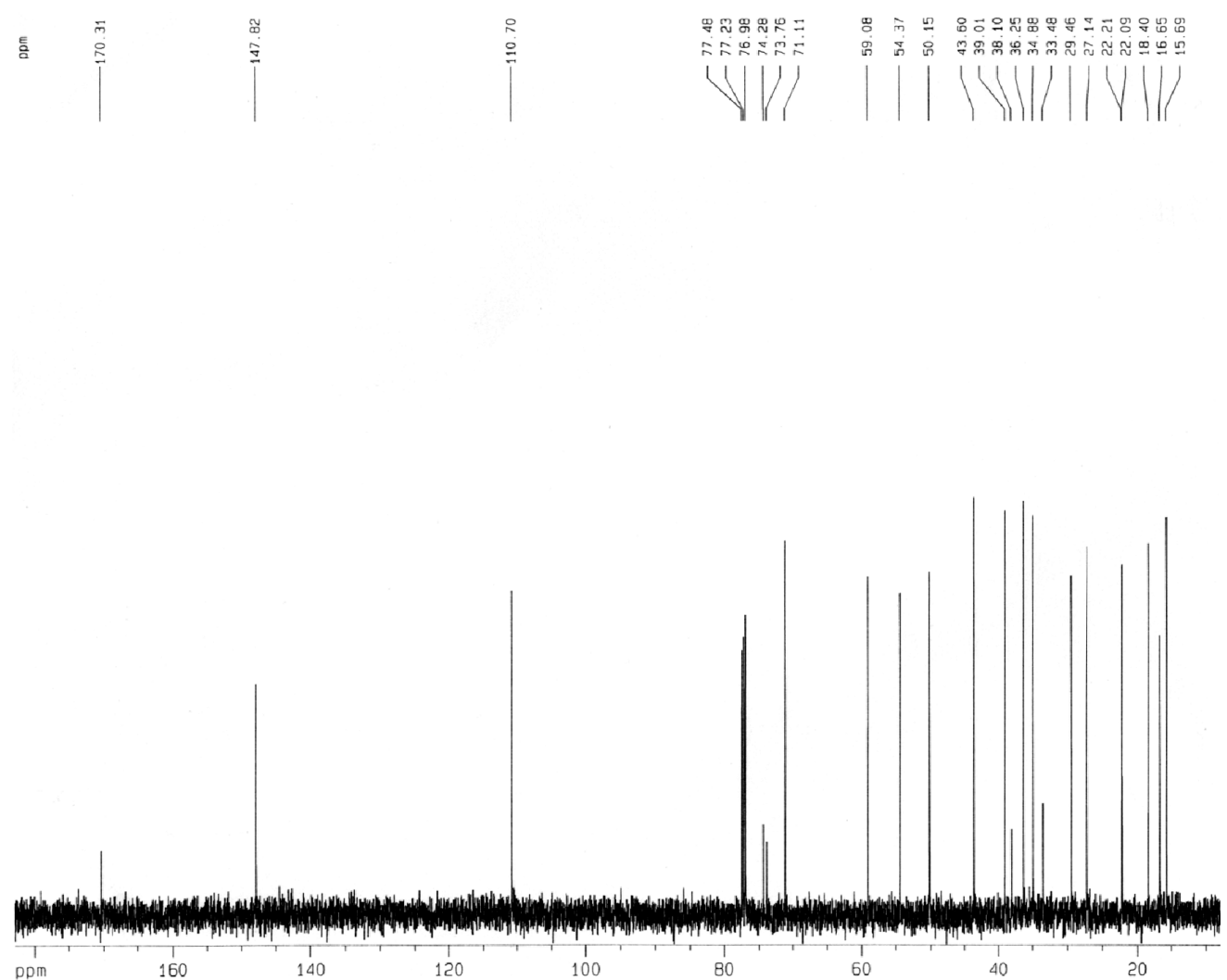

Figure S4. ${ }^{13} \mathrm{H}$ NMR spectrum of compound $\mathbf{1}\left(\mathrm{CDCl}_{3}, 125 \mathrm{MHz}\right)$. 


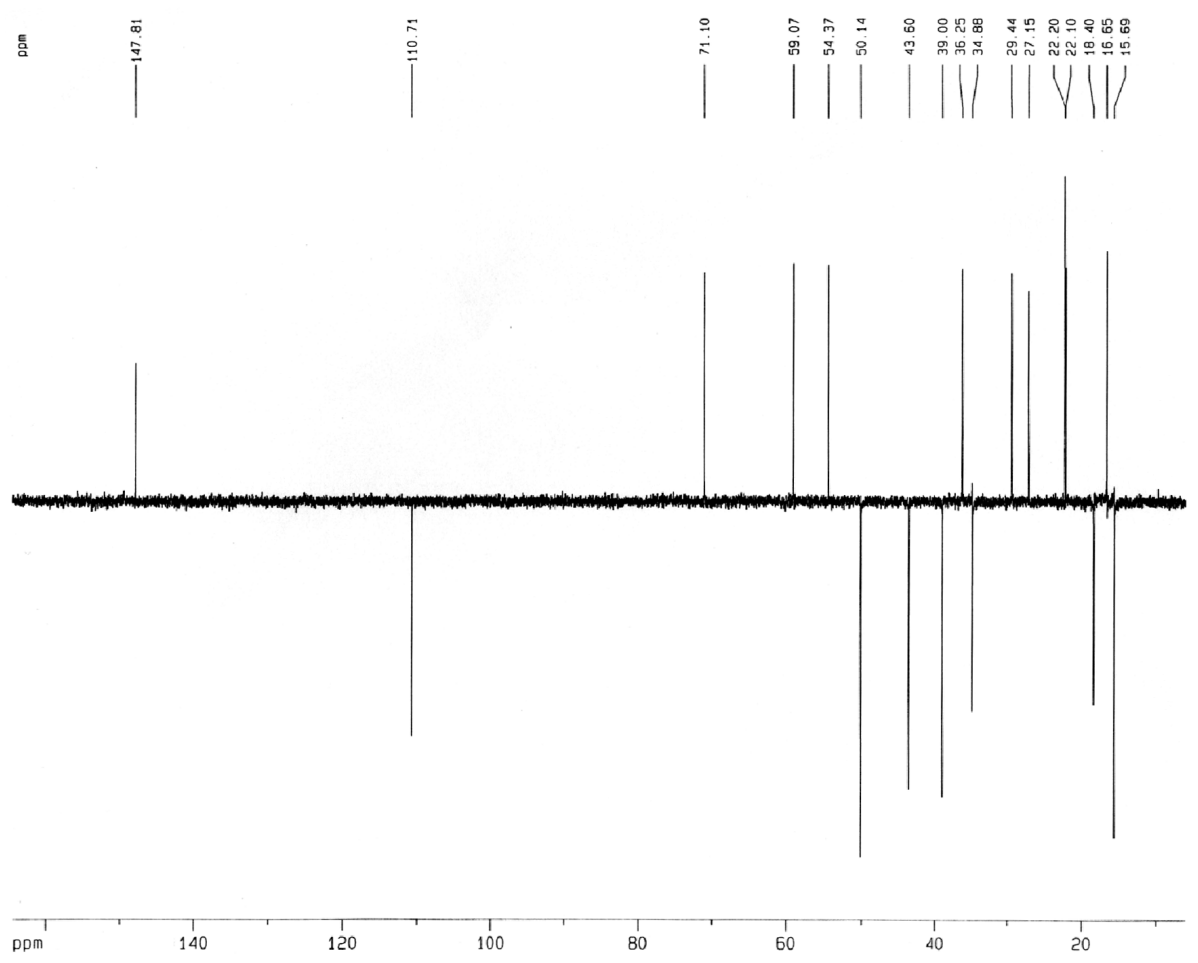

Figure S5. ${ }^{13} \mathrm{H}$ NMR - DEPT spectrum of compound $\mathbf{1}\left(\mathrm{CDCl}_{3}, 125 \mathrm{MHz}\right)$.

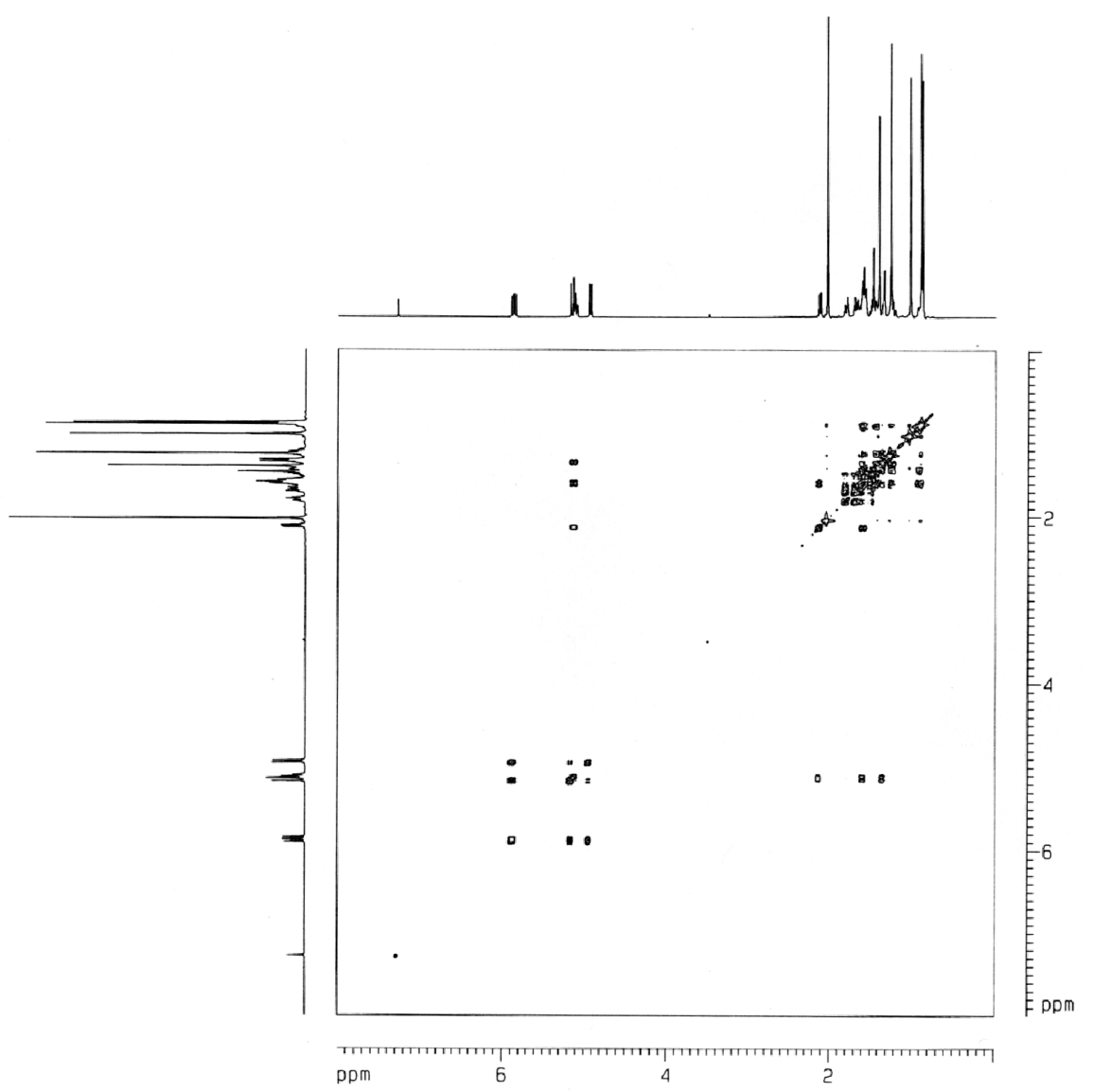

Figure S6. ${ }^{1} \mathrm{H},{ }^{1} \mathrm{H}$ COSY spectrum of compound $\mathbf{1}\left(\mathrm{CDCl}_{3}\right)$. 


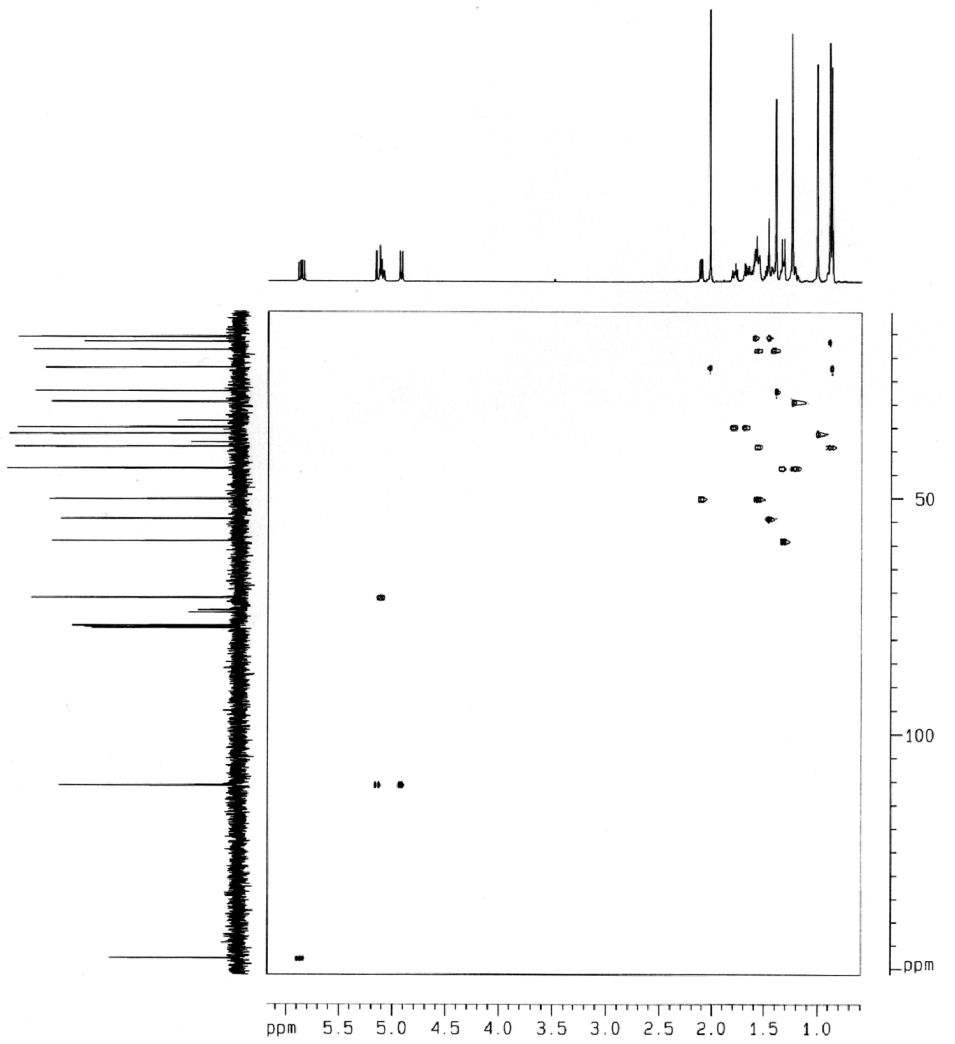

Figure S7. HMQC spectrum of compound d $\mathbf{1}\left(\mathrm{CDCl}_{3}\right)$.

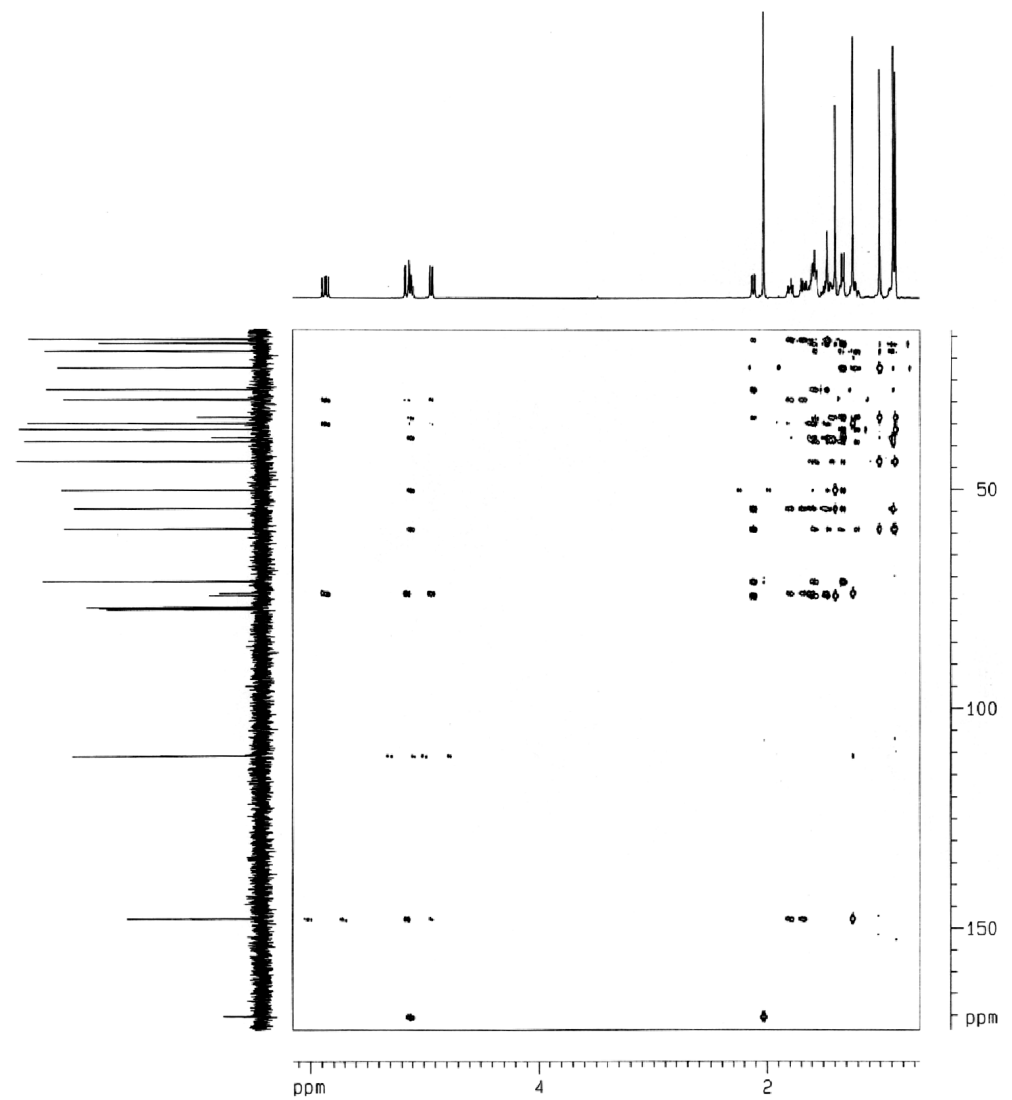

Figure S8. HMBC spectrum of compound $\mathbf{1}\left(\mathrm{CDCl}_{3}\right)$. 


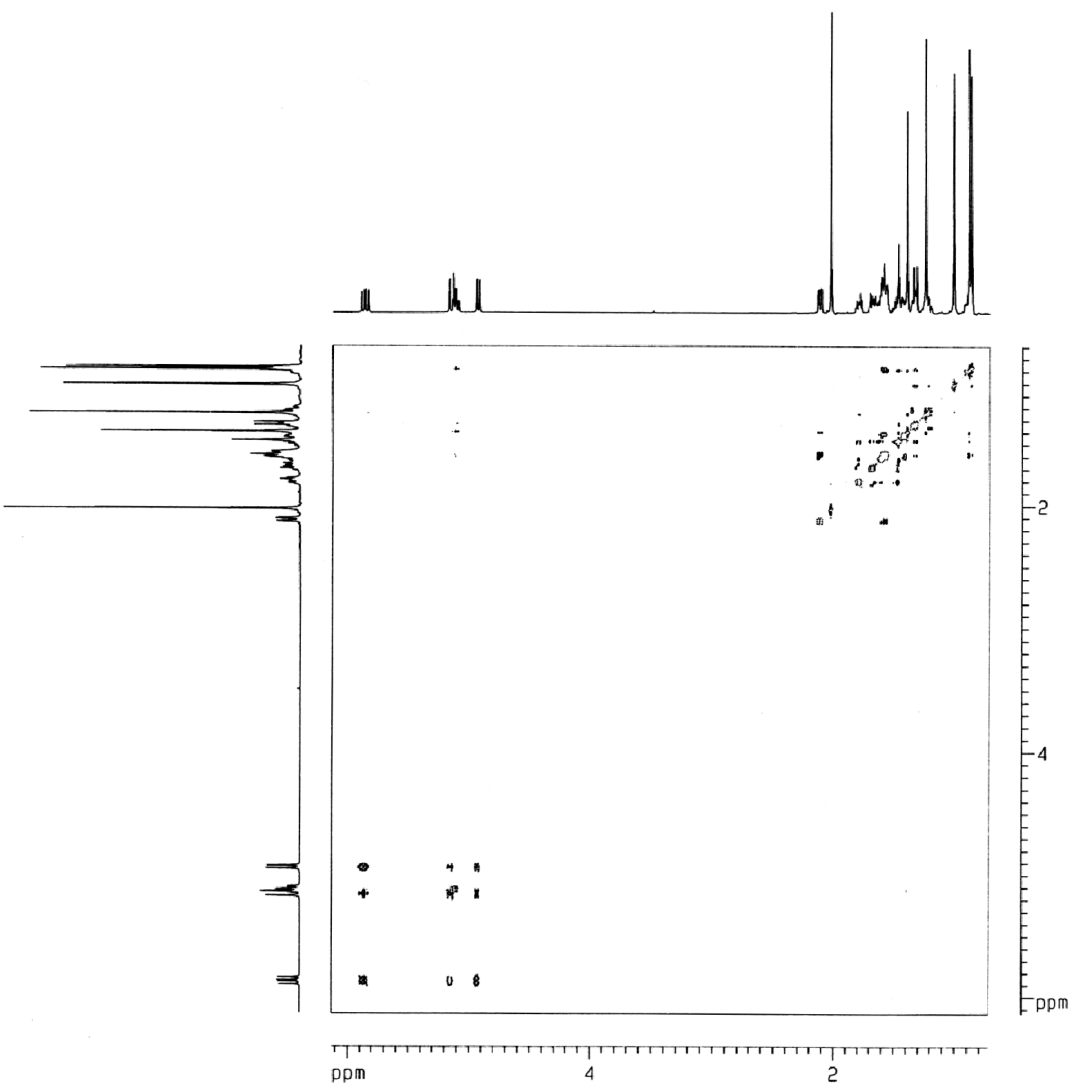

Figure S9. NOESY spectrum of compound $\mathbf{1}\left(\mathrm{CDCl}_{3}\right)$.

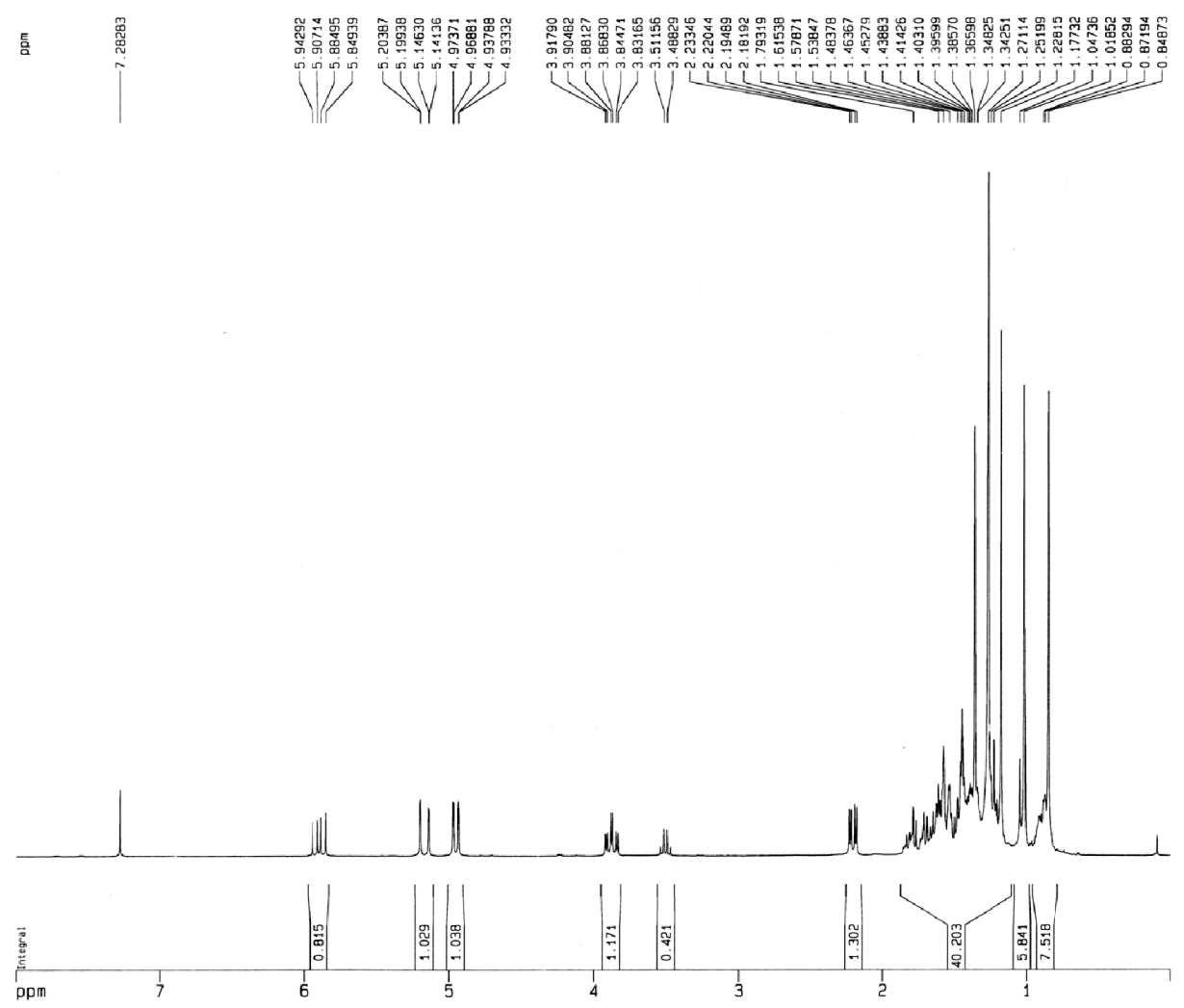

Figure S10. ${ }^{1} \mathrm{H}$ NMR spectrum of compound $2\left(\mathrm{CDCl}_{3}, 300 \mathrm{MHz}\right)$. 


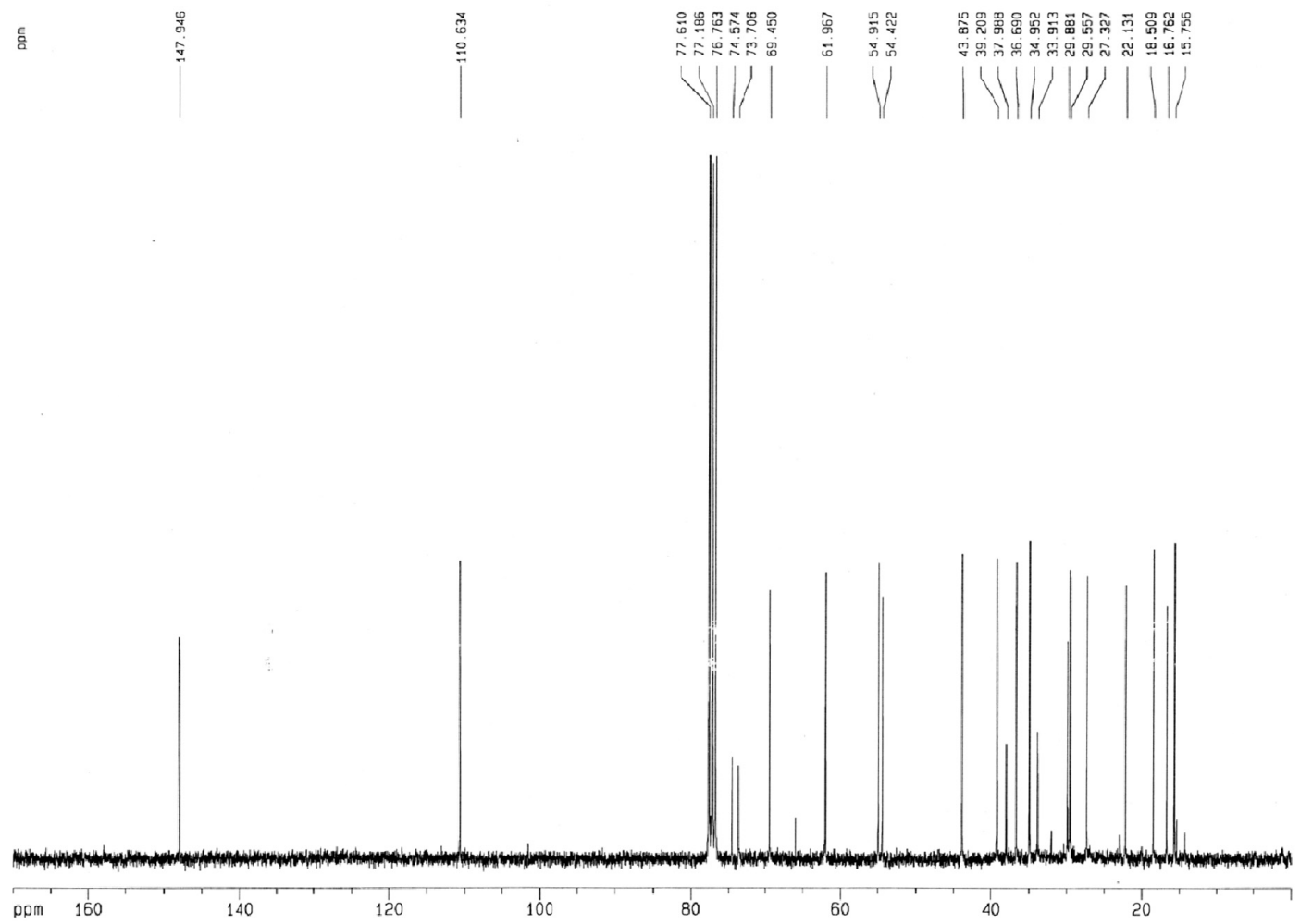

Figure S11. ${ }^{13} \mathrm{C}$ NMR spectrum of compound $2\left(\mathrm{CDCl}_{3}, 75 \mathrm{MHz}\right)$.
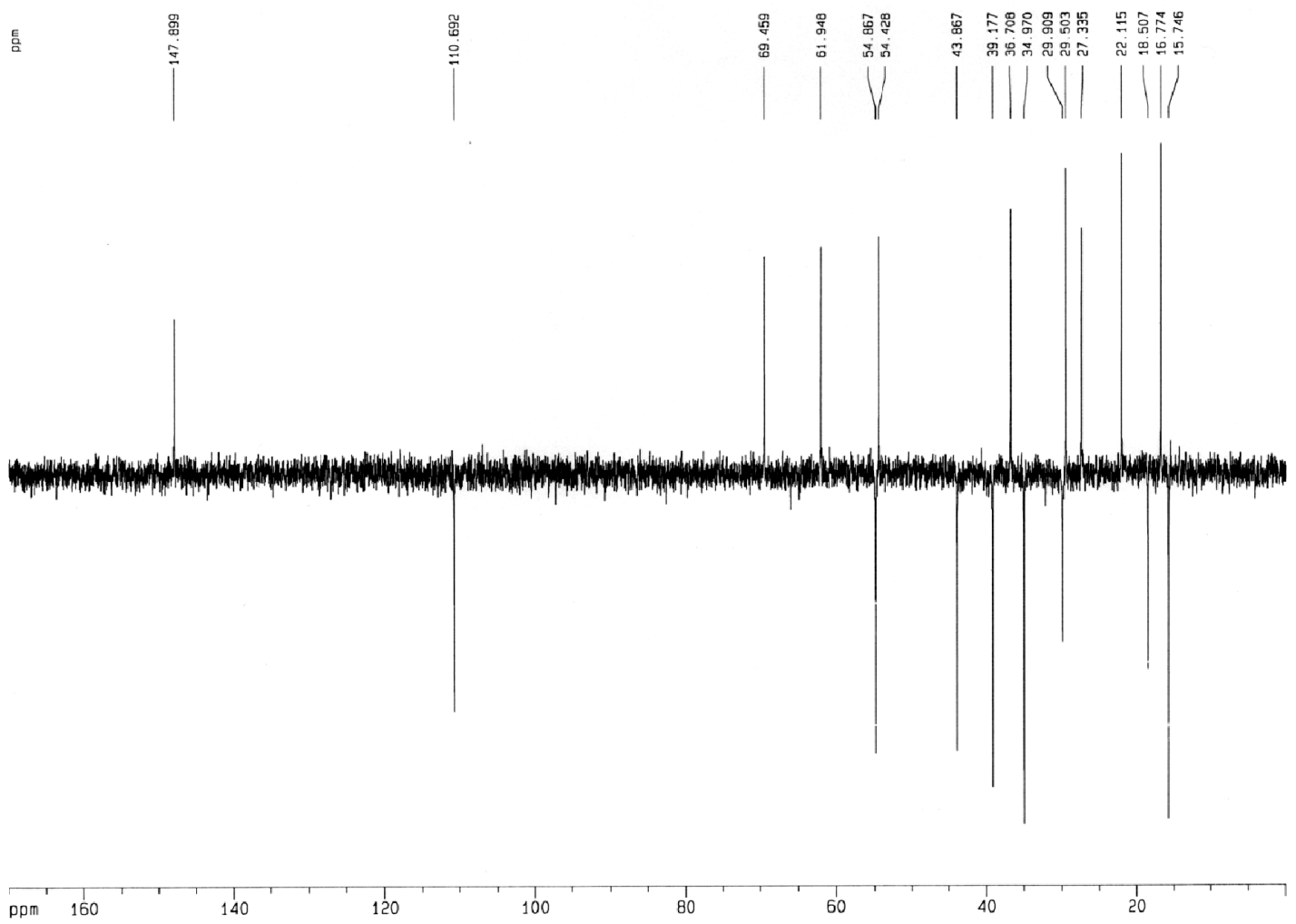

Figure S12. ${ }^{13} \mathrm{C}$ NMR - DEPT spectrum of compound $2\left(\mathrm{CDCl}_{3}, 75 \mathrm{MHz}\right)$. 


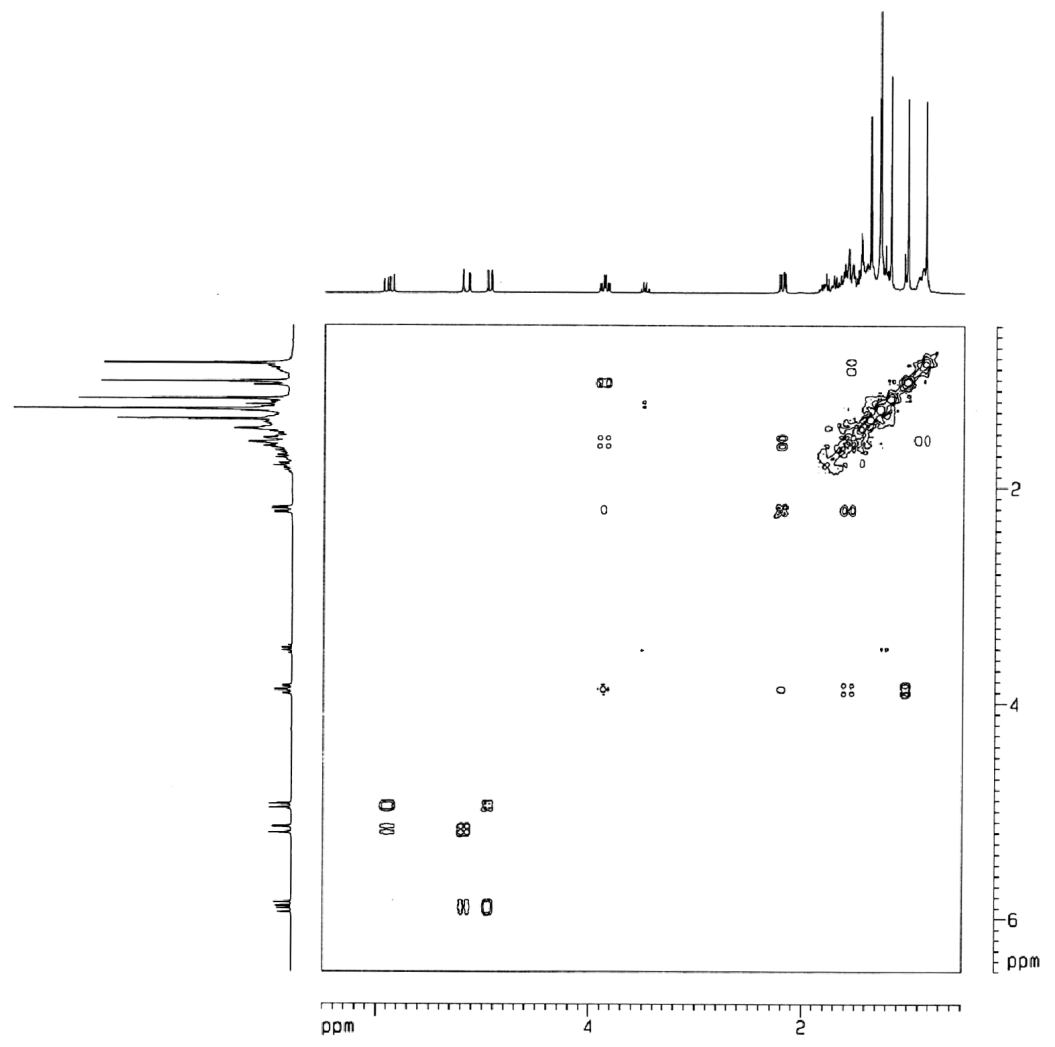

Figure S13. ${ }^{1} \mathrm{H},{ }^{1} \mathrm{H}$ COSY spectrum of compound $2\left(\mathrm{CDCl}_{3}\right)$.

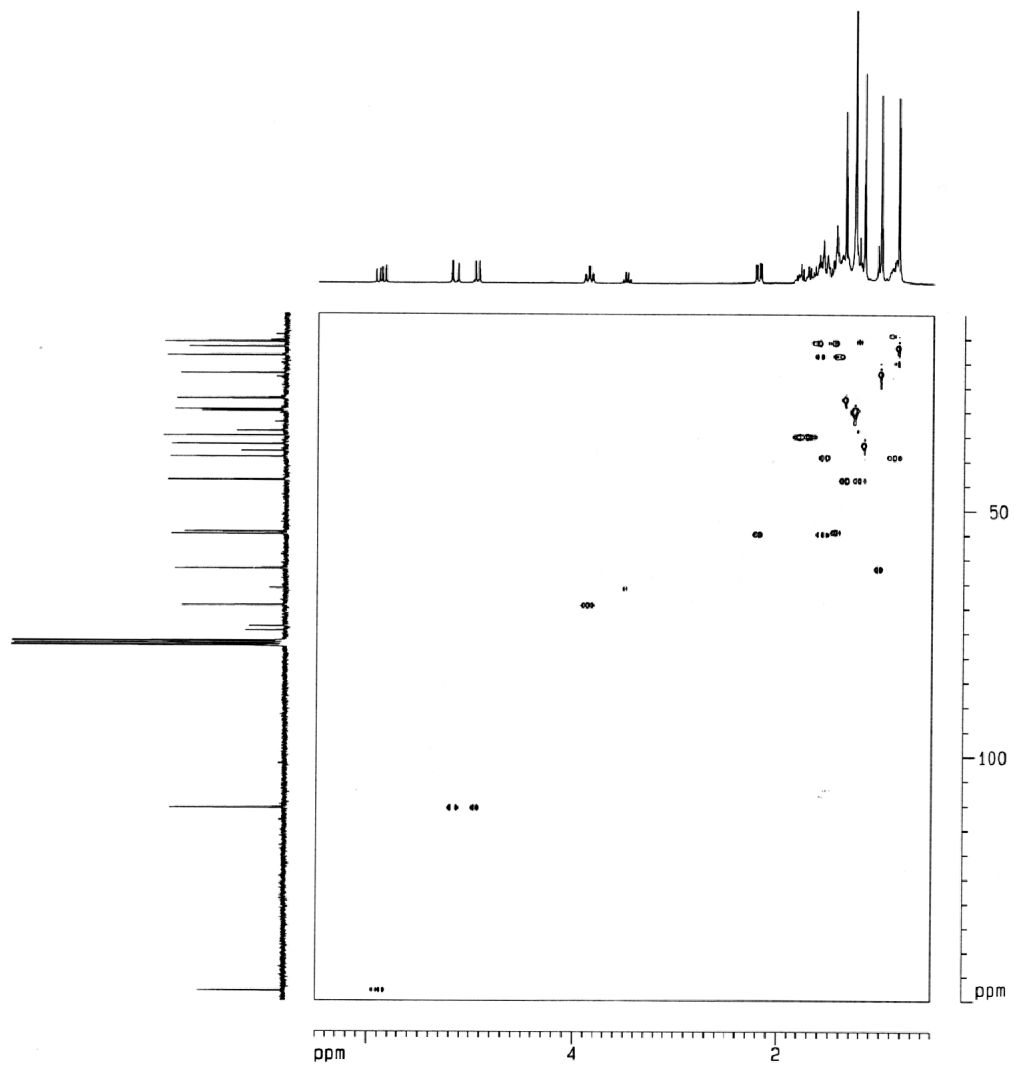

Figure S14. HMQC spectrum of compound $2\left(\mathrm{CDCl}_{3}\right)$. 


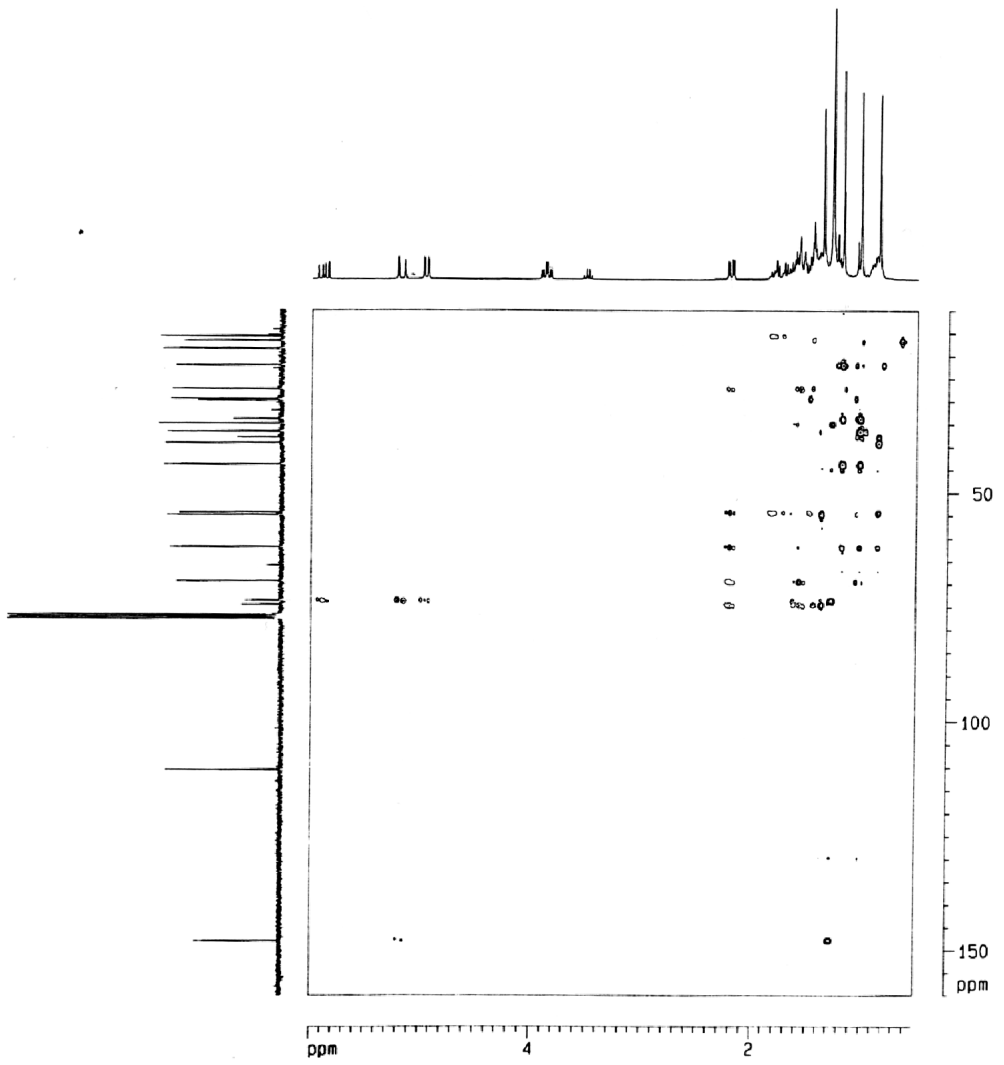

Figure S15. HMBC spectrum of compound $2\left(\mathrm{CDCl}_{3}\right)$.

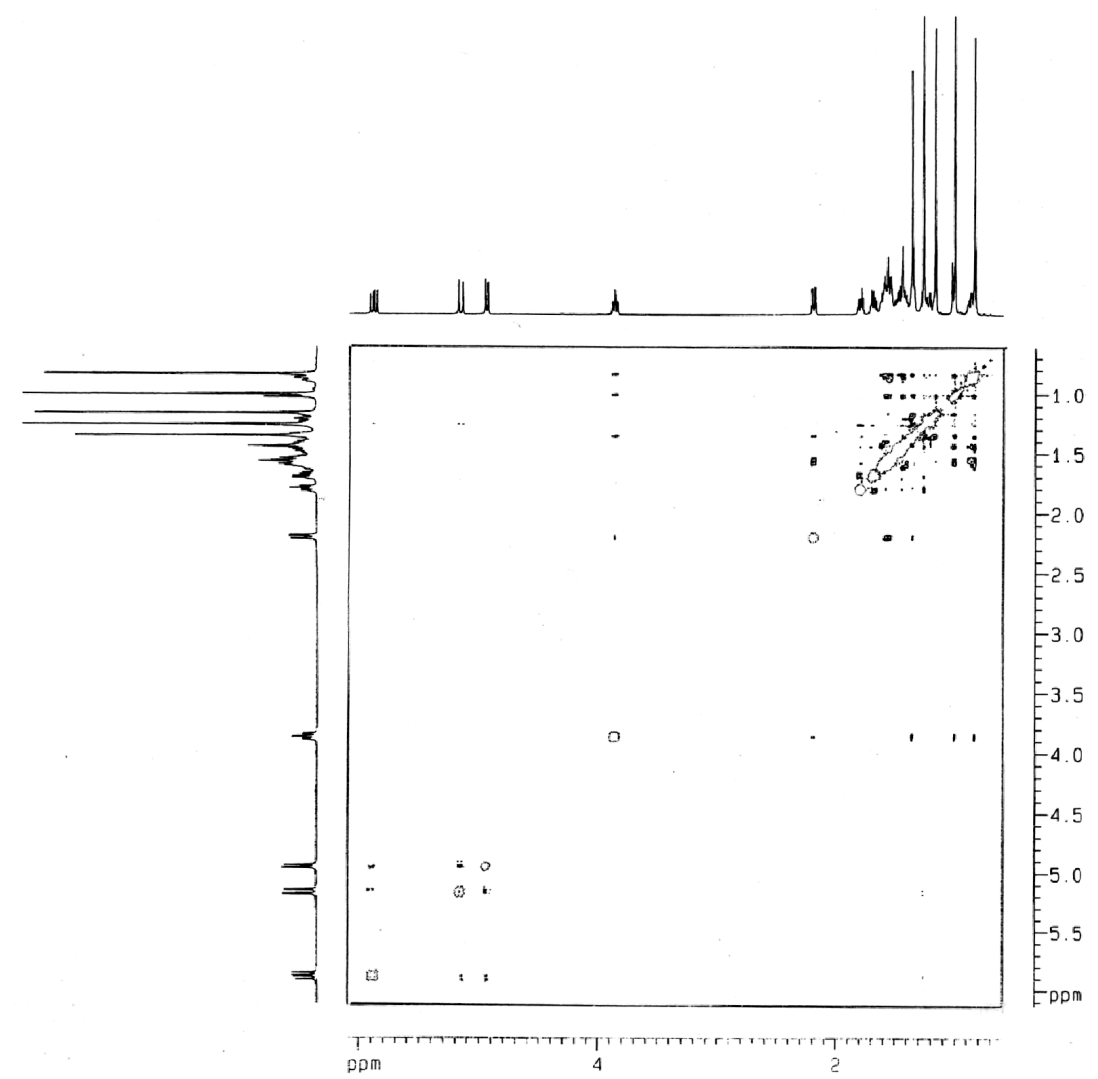

Figure S16. NOESY spectrum of compound $2\left(\mathrm{CDCl}_{3}\right)$. 